\title{
INFLUENCE OF SOME COMPOUNDS AS ANTITRANSPIRANT AGENTS ON GROWTH AND YIELD OF PELARGONIUM GRAVEOLENS PLANT
}

\author{
M.M. Moussa \\ Horticulture Dept., Fac. of Agric., Menoufia Univ., Shebin El-Kom, Egypt. \\ Received: Feb. 27,2019 \\ Accepted: Mar. 17, 2019
}

\begin{abstract}
An investigation concerning Pelargonium graveolens plant was carried out during two successive growing seasons of (2013 and 2014) at the Experimental Farm, Faculty of Agriculture, Menoufia University, Shebin EI - Kom, Egypt. This study was designed to determine the efficiency of antitranspirant agents i.e., magnesium carbonate (MgCO3) and sodium salicylate (S.S) at (10, 20 and 30 ppm) which used as chemical antitranspirant and active dry yeast (ADY) at $(5,10$ and $15 \mathrm{~g} / \mathrm{l})$ which used as natural antitranspirant on growth, yield and active constituents of geranium plant (Pelargonium graveolens) grown on a clayey soil.
\end{abstract}

Results reported that, all antitranspirant agents at different concentrations had a significant effects on growth and yield characters such as plant height (cm), number of main branches/plant, fresh weight of herb (g/plant) and fresh weight of leaves (g/plant and ton/fed) in the $1^{\text {st }}$ and $2^{\text {nd }}$ cuts during two seasons. Their maximum values in this concern were found in plants sprayed with active dry yeast (ADY) at $10 \mathrm{~g} / \mathrm{l}$ in two cuts during both seasons. Also, the application of sodium salicylate at (20 and $30 \mathrm{ppm}$ ) produced the highest oil content (\%) for the $1^{\text {st }}$ and $2^{\text {nd }}$ cuts, respectively during both seasons. Moreover, geraniol, linalool, gerannyl tiglate and cis-rose oxide were found to be the major compounds in the essential oil of Pelargonium graveolens which reached its maxima by spraying (ADY) at $10 \mathrm{mg} / \mathrm{l},(A D Y)$ at $15 \mathrm{mg} / \mathrm{l},(\mathrm{S} . \mathrm{S})$ at $20 \mathrm{ppm}$ and (S.S) at 30 ppm, respectively during second cut in the first season.

Key words: Pelargonium graveolens, Growth and yield characters, Antitranspirants, Chemical compositions

\section{INTRODUCTION}

Pelargonium graveolens (geranium plant) belongs to family Geraniacea is native to South Africa and widely cultivated in different countries i.e., China, Russia, Algeria, Morocco, Madagascar and Egypt (Shawl et al., 2006 and Verma et al., 2011). Pelargonium graveolens oil is one of the most important volatile oil which produced in Egypt for exportation and local market. The essential oil in the geranium herb can be obtained by steam distillation of the leaves. The main constituents of the essential oil are citronellol, geraniol, linalool, iso-menthone, citronellyl formate and geraniol formate (Miller, 2002 and
Peterson et al., 2005). Geranium oil has many uses in fragrance industries (Singh et al., 2008), cosmetic industries (Shawl et al., 2006) and food and pharmaceutical industries (Rao, 2002). It is also considered one of the best skincare oil because it is good in cleaning oily complexions and opening skin pores (Peterson et al., 2005). Furthermore (Peterson et al., 2005) reported that, geranium oil is more useful for eczema and athlete foot problems. Also, the leaves of Pelargonium graveolens are used as a form of herbal tea to de-stress, ease tension, fight anxiety and to cure tonsillitis. 
One of the main sensitive environmental factors affecting geranium plant growth and development is water status. The plants used $5 \%$ from water absorption to growth and nearly $95 \%$ were lost to transpiration (Prakash and Ramachandran, 2000). Thus, it is perfect to keep pace with transpiration and water uptake by roots. Reduction transpiration by using antitranspirant could save huge quantities of water and also minimize plant stress due to water deficits. The application of antitranspirants may decrease transpiration in three different ways: i) reflecting materials, which reduces the heat load on leaves, ii) thin film forming materials, which hinder the escape of water vapor from the leaves and stomata, iii) closing materials, which increase stomata resistance. Pinto and Torres-Pereira (2006) found that, the reflective coating foliar application of antitranspirant on Quercus suber plants reduced leaf temperature and water loss. The study of Del Amor et al. (2010) mentioned that, antitranspirant did not affect photosynthesis rate, meanwhile, leaf temperatures, stomatal conductance and transpiration rate of sweet pepper plants were decreased. Jifon and Syvertsen (2003) investigated that, the application of antitranspirant increases reflectance and decrease midday leaf temperature.

\section{MATERIALS AND METHODS}

This experiment was carried out through two successive growing seasons of (2013 and 2014 ) at the Experimental Farm, Faculty of Agriculture, Menoufia University, Shebin El - Kom , Egypt $\left(30.52^{\circ} \mathrm{N}\right.$ and $\left.30.99^{\circ} \mathrm{E}\right)$, to evaluate the efficiency of antitranspirant agents i.e., magnesium carbonate $\left(\mathrm{MgCO}_{3}\right)$ and sodium salicylate (S.S) at $(10,20$ and 30 ppm) which used as chemical antitranspirant and active dry yeast (ADY) at (5, 10 and $15 \mathrm{~g} / \mathrm{l})$ which used as natural antitranspirant on growth, yield and active constituents of geranium plants (Pelargonium graveolens) grown on a clayey soil. Representative surface soil samples $(0-30 \mathrm{~cm})$ were collected from the used soil before performance of the experiment. Soil samples were air dried, ground, mixed well, sieved through a $2 \mathrm{~mm}$ sieve. The samples then were analyzed for determination of some physical and chemical properties. Also, the contents of some available macro and micronutrients were described according to the methods by Cottenie et al. (1982); Page et al. (1982) and Kim (1996). The obtained data were recorded in Table (1).

The experiment was arranged in a randomized complete blocks design with three replicates. The experimental plots were 30 units $(10$ treatments $\times 3$ replicates) for each cut during two seasons. The area of each plot (unit) was $3.6 \mathrm{~m}^{2}(1.8 \mathrm{~m} \times 2 \mathrm{~m})$ including four ridges and the distance between plants is 30 $\mathrm{cm}$. All plants received mineral NPK as ammonium nitrate $(33.5 \% \mathrm{~N})$ at 400 $\mathrm{kg} / \mathrm{fed} / \mathrm{year}$, calcium superphosphate $\left(15.5 \% \mathrm{P}_{2} \mathrm{O}_{5}\right)$ at $300 \mathrm{~kg} / \mathrm{fed} / \mathrm{year}$ and potassium sulphate $\left(48 \% \mathrm{~K}_{2} \mathrm{O}\right)$ at 300 $\mathrm{kg} / \mathrm{fed} / \mathrm{year}$, respectively. All $\mathrm{P}$ amount was added during preparation the soil to cultivation, while the mineral $\mathrm{N}$ and $\mathrm{K}$ were divided in two equal groups at 14 days after planting and 10 days after harvesting the $1^{\text {st }}$ cut through the first and second seasons. Foliar application of antitranspirants were occurred after three weeks from planting and repeated monthly in the early morning till the end of the experiment. Spraying was done till all plants were completely covered with the antitranspirants. 
Table (1) : Some physical and chemical properties of the used soil

\begin{tabular}{|c|c|c|c|c|c|c|c|c|c|c|c|c|}
\hline \multirow{3}{*}{$\begin{array}{l}\text { Physical } \\
\text { properties }\end{array}$} & \multicolumn{6}{|c|}{$\begin{array}{c}\text { Particles size distribution } \\
(\%)\end{array}$} & \multirow{2}{*}{$\begin{array}{c}\text { Textura } \\
\text { grade }\end{array}$} & \multicolumn{2}{|c|}{ ensity } & \multirow{2}{*}{\multicolumn{2}{|c|}{$\begin{array}{c}\text { Total } \\
\text { porosity } \\
(\%)\end{array}$}} & \multirow{2}{*}{$\begin{array}{c}\text { Water } \\
\text { field } \\
\text { capacity } \\
(\%)\end{array}$} \\
\hline & \multicolumn{2}{|c|}{ Coarse sand } & $\begin{array}{l}\text { Fine } \\
\text { sand }\end{array}$ & Silt & \multicolumn{2}{|r|}{ Clay } & & \multicolumn{2}{|c|}{$\left(\mathrm{Mg} / \mathrm{m}^{3}\right)$} & & & \\
\hline & \multicolumn{2}{|c|}{6.62} & 14.22 & 28.5 & & 50.66 & Claye & 1. & & & 9.81 & 34.5 \\
\hline \multirow{3}{*}{$\begin{array}{l}\text { Chemical } \\
\text { properties }\end{array}$} & \multirow{2}{*}{$\begin{array}{c}\mathrm{pH} \\
1: 2.5 \\
\text { soil : } \\
\text { water } \\
\text { susp. }\end{array}$} & \multirow{2}{*}{$\begin{array}{c}\text { EC } \\
\text { (soil } \\
\text { paste) } \\
\text { dS m }^{-1}\end{array}$} & \multicolumn{4}{|c|}{$\begin{array}{l}\text { Soluble cations } \\
\qquad(\text { meq } / \text { I ) }\end{array}$} & \multicolumn{3}{|c|}{$\begin{array}{l}\text { Soluble anions } \\
(\text { meq } I \text { I ) }\end{array}$} & \multirow{2}{*}{$\begin{array}{l}\text { OM } \\
(\%)\end{array}$} & \multirow{2}{*}{$\begin{array}{c}\text { CEC } \\
(\mathrm{cmol} / \\
\mathrm{kg})\end{array}$} & \multirow{2}{*}{$\begin{array}{c}\mathrm{Ca} \mathrm{CO}_{3} \\
(\%)\end{array}$} \\
\hline & & & $\mathrm{Na}^{+}$ & $\mathrm{K}^{+}$ & $\mathrm{Ca}^{2+}$ & $\mathrm{Mg}^{2+}$ & $\mathrm{Cl}^{-}$ & $\mathrm{HCO}_{3}^{-}$ & $\mathrm{SO}_{4}^{2-}$ & & & \\
\hline & 7.81 & 2.03 & 9.1 & 2.81 & 5.21 & 3.18 & 11.13 & 2.19 & 6.98 & 1.97 & 34.20 & 3.22 \\
\hline \multirow{3}{*}{$\begin{array}{l}\text { Available } \\
\text { nutrients }\end{array}$} & \multicolumn{5}{|c|}{ Macronutrients ( $\mathrm{mg} / \mathrm{kg}$ ) } & \multicolumn{7}{|c|}{ Micronutrients ( $\mathrm{mg} / \mathrm{kg}$ ) } \\
\hline & \multicolumn{2}{|c|}{$\mathbf{N}$} & $\mathbf{P}$ & 1 & $\mathrm{~K}$ & $\mathrm{Fe}$ & \multicolumn{2}{|c|}{ Mn } & \multicolumn{2}{|c|}{$\mathrm{Zn}$} & \multicolumn{2}{|r|}{ B } \\
\hline & \multicolumn{2}{|c|}{45.00} & 7.21 & & 54 & 10.42 & \multicolumn{2}{|c|}{4.11} & 3.2 & & \multicolumn{2}{|c|}{1.16} \\
\hline
\end{tabular}

Uniform plants of Pelargonium graveolens (15 cm in height) were secured from Medicinal and Aromatic Plants Res. Dept., Hort. Res. Inst., Agricultural Research Centre, Ministry of Agriculture, Giza, Egypt and were transplanted on the first of March during two growing seasons, 2013 and 2014. All agricultural practices beginning from transplanting to harvesting were performed as recommended by Egyptian Ministry of Agriculture.

The plant samples were harvested (cutting) twice after 6 and 9 months from transplanting in each season and taken carefully from each replicate to estimate the following parameters:

\section{1- Vegetative growth characters:}

Plant height $(\mathrm{cm})$, number of main branches/plant, fresh weight of herb (g/plant) and fresh weight of leaves (g/plant and ton/fed.). A portion of each herb sample was air - dried, oven - dried at $70{ }^{\circ} \mathrm{C}$ for $72 \mathrm{hrs}$. and dry weights were measured as (g/plant).

\section{2- Chemical constituents}

Photosynthetic pigments (chlorophyll $a, b$ and carotenoids) were determined in fresh leaves (mg/g fresh weight) as the methods described by Witham et al. (1971).

Essential oil percentages were determined in the fresh leaves through the $1^{\text {st }}$ and $2^{\text {nd }}$ cuts in both seasons as described by British (1963).

The volatile oil obtained from the fresh leaves in the $2^{\text {nd }}$ cut during the first season was analyzed by using GLC Model HP-5890 with flame ionization detector that was fitted with capillary column, coated with carbowax 20M. The operating conditions were injector temperature $190^{\circ} \mathrm{C}$, detector temperature $110^{\circ} \mathrm{C}$, linear temperature programmed at $5{ }^{\circ} \mathrm{C} \mathrm{min}$, to $175{ }^{\circ} \mathrm{C} \mathrm{min}$, nitrogen (carrier gas) flow $2 \mathrm{ml} / \mathrm{min}$, hydrogen 30 $\mathrm{ml} / \mathrm{min}$, air $330 \mathrm{ml} / \mathrm{min}$. The peaks were recorded and the areas were determined by using HP-integrator. Oil components 
were identified by comparing the relation times of the authentic compound.

Plant samples were washed several times with a tap-water and then two times with distilled water, air-dried, oven-dried at $70^{\circ} \mathrm{C}$ for 48 hour, ground separately to a fine powder in a stainless grinder and stored in plastic bags until analysis. Total carbohydrate (\%) in the dried herb of geranium plants was determined by using the colorimetric method which described by Dubois et al. (1956). A half $g$ portion of each dried plant sample was digested by $5 \mathrm{ml}$ of concentrated mixture of $\mathrm{H}_{2} \mathrm{SO}_{4}+\mathrm{HClO}_{4}$ at (5: 0.5 ratio) according to Chapman and Pratt (1982). The content (\%) of $N, P$ and $K$ were determined as described by Cottenie et al. (1982).

\section{Statistical analysis}

The obtained data of growth parameters were exposed to proper statistical analyses of variance (ANOVA) by using Minitab computer program and least significant difference (L.S.D.) were calculated at level of $5 \%$ (Barbara and Brain, 1994).

\section{RESULTS AND DISCUSSION}

Effect of foliar application of antitranspirant agents on :

\section{Growth and yield characters}

Antitranspirant treatments have been proposed as a method to minimize water loss and therefor improve the water status of plants. Data in Table (2) reported that, the effect of foliar spraying by active dry yeast (ADY), magnesium carbonate $\left(\mathrm{MgCO}_{3}\right)$ and sodium salicylate (S.S) at different concentrations increased growth and yield parameters of geranium plants expressed as plant height (cm), number of main branches/plant, fresh weight of herb (g/plant) and fresh weight of leaves (g/plant and ton/fed.) as follows: ADY >
S.S $>M g C O 3>$ in the $1^{\text {st }}$ and $2^{\text {nd }}$ cuts through two seasons. The best results in these traits were obtained from using active dry yeast (ADY) at $10 \mathrm{~g} / \mathrm{l}$ in two cuts during both seasons comparing with control.

The positive enhancement of these materials on growth and yield parameters could be explained through their effects on making powder (film) on the surface of leaf which can keep the plant from heat damage of reflected sunrays and also it can enhancing cell division and the biosynthesis (Nasraui, 1993). Also antitranspirant treatments reduce the transpiration rate by smaller stomata opening (Bittelli et al., 2001). The obtained results are in line with Cantore et al. (2009) on tomato plants and Ibrahim and Selim (2010) on summer squash plants.

\section{Essential oil production}

It was clear from Table (3) that, the application of both natural (ADY) and $\begin{array}{llll}\text { chemical } & \left(\mathrm{MgCO}_{3} \text { and }\right. & \text { S.S) }\end{array}$ antitranspirants significantly increased essential oil production which include oil content (\%) and oil yield (cc/plant and l/fed) compared to untreated plant through the $1^{\text {st }}$ and $2^{\text {nd }}$ cuts during two seasons. Generally, the application of S.S at different concentrations were more effective on oil production followed by using $\mathrm{MgCO}_{3}$ and then $\mathrm{ADY}$ in most cases during two cuts in both seasons. The highest increments in oil content (\%) and oil yield (cc/plant and I/fed) were found by using S.S at $20 \mathrm{ppm}$ and $30 \mathrm{ppm}$ for the first and second cuts, respectively during two seasons.

Using antitranspirant improved the water use efficiency (Bose et al., 2001) by reducing leaf transpiration rate via increasing leaf reflecting or inducing stomata closure (Tezara et al., 1996) and that is led to an increase in 
photosynthesis (Fukutoka and Terai, 1996). As the volatile oil is secondary output of photosynthesis, so the application of antitranspirants enhance volatile oil content. These results are similar to those obtained by Leithy et al (2015) on canola plants.

Table (2): Effect of foliar application of antitranspirants on growth and yield characters of geranium plants in two cuts during both seasons.

\begin{tabular}{|c|c|c|c|c|c|c|c|c|c|c|}
\hline \multirow{3}{*}{ Treatments } & \multicolumn{2}{|c|}{$\begin{array}{l}\text { Plant height } \\
\text { (cm) }\end{array}$} & \multicolumn{2}{|c|}{$\begin{array}{c}\text { Number of main } \\
\text { branches/plant }\end{array}$} & \multicolumn{2}{|c|}{$\begin{array}{l}\text { Fresh weight } \\
\text { of herb (gl } \\
\text { plant) }\end{array}$} & \multicolumn{2}{|c|}{$\begin{array}{l}\text { Fresh weight } \\
\text { of leaves } \\
\text { (g/plant) }\end{array}$} & \multicolumn{2}{|c|}{$\begin{array}{l}\text { Fresh weight } \\
\text { of leaves } \\
\text { (ton/fed) }\end{array}$} \\
\hline & \multicolumn{10}{|c|}{ First season } \\
\hline & $1^{\text {st }}$ cut & $2^{\text {nd }}$ cut & $1^{\text {st }}$ cut & $2^{\text {nd }}$ cut & $1^{\text {st }}$ cut & $2^{\text {nd }}$ cut & $1^{\text {st }}$ cut & $2^{\text {nd }} c u t$ & $1^{\text {st }}$ cut & $2^{\text {nd }}$ cut \\
\hline Control & 47.26 & 45.12 & 9.68 & 10.80 & 353.47 & 384.16 & 183.57 & 199.08 & 4.89 & 5.31 \\
\hline ADY $5 \mathrm{~g} / \mathrm{l}$ & 62.40 & 60.16 & 11.94 & 13.59 & 445.72 & 476.48 & 243.80 & 261.49 & 6.50 & 6.97 \\
\hline ADY $10 \mathrm{~g} / \mathrm{l}$ & 68.11 & 65.93 & 13.35 & 14.77 & 481.19 & 513.67 & 266.75 & 285.62 & 7.11 & 7.61 \\
\hline ADY $15 \mathrm{~g} / \mathrm{l}$ & 66.16 & 63.54 & 12.05 & 12.87 & 433.51 & 460.94 & 231.45 & 250.19 & 6.17 & 6.67 \\
\hline SS 10 ppm & 56.28 & 57.69 & 11.62 & 11.83 & 407.84 & 431.53 & 226.19 & 240.51 & 6.03 & 6.41 \\
\hline SS 20 ppm & 59.23 & 51.77 & 12.87 & 13.66 & 448.60 & 452.74 & 239.80 & 249.78 & 6.39 & 6.66 \\
\hline SS 30 ppm & 55.87 & 55.23 & 10.45 & 13.70 & 396.17 & 443.40 & 215.63 & 242.49 & 5.75 & 6.46 \\
\hline $\mathrm{MgCO}_{3} 10 \mathrm{ppm}$ & 53.61 & 52.87 & 10.38 & 12.80 & 384.51 & 421.85 & 207.32 & 231.90 & 5.53 & 6.18 \\
\hline $\mathrm{MgCO}_{3} 20 \mathrm{ppm}$ & 51.50 & 49.51 & 11.22 & 12.04 & 372.66 & 403.16 & 203.12 & 221.92 & 5.42 & 5.92 \\
\hline $\mathrm{MgCO}_{3} 30 \mathrm{ppm}$ & 48.66 & 45.40 & 10.15 & 10.93 & 359.70 & 395.76 & 191.40 & 214.53 & 5.10 & 5.72 \\
\hline L.S.D. at 5\% & 3.24 & 3.08 & 1.16 & 1.57 & 38.65 & 43.65 & 19.69 & 21.36 & 0.77 & 0.91 \\
\hline \multicolumn{11}{|c|}{ Second season } \\
\hline Control & 49.83 & 44.15 & 11.36 & 11.92 & 375.12 & 396.25 & 200.55 & 213.17 & 5.35 & 5.68 \\
\hline ADY $5 \mathrm{~g} / \mathrm{l}$ & 60.72 & 61.86 & 12.17 & 14.15 & 463.40 & 494.38 & 251.88 & 270.25 & 6.72 & 7.20 \\
\hline ADY $10 \mathrm{~g} / \mathrm{l}$ & 64.33 & 66.90 & 15.49 & 16.30 & 495.17 & 521.74 & 275.19 & 291.85 & 7.34 & 7.78 \\
\hline ADY $15 \mathrm{~g} / \mathrm{l}$ & 61.84 & 59.11 & 14.67 & 14.28 & 446.81 & 478.63 & 242.70 & 258.36 & 6.47 & 6.89 \\
\hline SS 10 ppm & 57.93 & 55.20 & 13.09 & 13.17 & 419.53 & 449.35 & 231.41 & 242.45 & 6.17 & 6.46 \\
\hline SS 20 ppm & 60.58 & 55.42 & 13.72 & 14.68 & 434.61 & 465.42 & 240.93 & 250.01 & 6.42 & 6.67 \\
\hline SS 30 ppm & 53.76 & 51.25 & 12.40 & 12.35 & 402.77 & 424.16 & 219.15 & 234.30 & 5.84 & 6.25 \\
\hline $\mathrm{MgCO}_{3} 10 \mathrm{ppm}$ & 54.19 & 49.94 & 12.19 & 13.70 & 393.80 & 418.37 & 216.60 & 222.16 & 5.77 & 5.92 \\
\hline $\mathrm{MgCO}_{3} 20 \mathrm{ppm}$ & 50.07 & 48.88 & 11.60 & 12.51 & 388.46 & 411.22 & 211.33 & 219.75 & 5.63 & 5.86 \\
\hline $\mathrm{MgCO}_{3} 30 \mathrm{ppm}$ & 50.36 & 45.75 & 11.73 & 11.88 & 381.53 & 395.60 & 200.68 & 215.60 & 5.35 & 5.75 \\
\hline L.S.D. at $5 \%$ & 2.97 & 6.87 & 1.58 & 2.09 & 46.82 & 51.33 & 20.37 & 30.18 & 0.86 & 1.26 \\
\hline
\end{tabular}


Table (3) : Effect of foliar application of antitranspirants on essential oil production of geranium plants in two cuts during both seasons.

\begin{tabular}{|c|c|c|c|c|c|c|}
\hline \multirow{3}{*}{ Treatments } & \multicolumn{2}{|c|}{ Oil \% } & \multicolumn{2}{|c|}{$\begin{array}{l}\text { Oil yield } \\
\text { (cc / plant) }\end{array}$} & \multicolumn{2}{|c|}{$\begin{array}{l}\text { Oil yield } \\
\text { ( } 1 / \text { fed) }\end{array}$} \\
\hline & \multicolumn{6}{|c|}{ First season } \\
\hline & $1^{\text {st }}$ cut & $2^{\text {nd }}$ cut & $1^{\text {st }}$ cut & $2^{\text {nd }}$ cut & $1^{\text {st }}$ cut & $2^{\text {nd }} c u t$ \\
\hline Control & 0.28 & 0.26 & 0.51 & 0.52 & 13.69 & 13.81 \\
\hline ADY $5 \mathrm{~g} / \mathrm{l}$ & 0.31 & 0.29 & 0.76 & 0.76 & 20.15 & 20.21 \\
\hline ADY $10 \mathrm{~g} / \mathrm{l}$ & 0.36 & 0.30 & 0.96 & 0.86 & 25.60 & 22.83 \\
\hline ADY $15 \mathrm{~g} / \mathrm{l}$ & 0.40 & 0.33 & 0.93 & 0.82 & 24.68 & 22.01 \\
\hline SS 10 ppm & 0.42 & 0.39 & 0.95 & 0.94 & 25.32 & 25.00 \\
\hline SS 20 ppm & 0.48 & 0.43 & 1.15 & 1.07 & 30.67 & 28.64 \\
\hline SS 30 ppm & 0.44 & 0.45 & 0.95 & 1.09 & 25.30 & 29.07 \\
\hline $\mathrm{MgCO}_{3} 10$ ppm & 0.38 & 0.34 & 0.79 & 0.78 & 21.01 & 21.01 \\
\hline $\mathrm{MgCO}_{3} 20$ ppm & 0.41 & 0.37 & 0.83 & 0.82 & 22.22 & 21.90 \\
\hline $\mathrm{MgCO}_{3} 30 \mathrm{ppm}$ & 0.41 & 0.35 & 0.78 & 0.75 & 20.91 & 20.02 \\
\hline \multirow[t]{2}{*}{ L.S.D. at $5 \%$} & 0.09 & 0.11 & 0.21 & 0.28 & 4.38 & 3.67 \\
\hline & \multicolumn{6}{|c|}{ Second season } \\
\hline Control & 0.30 & 0.29 & 0.60 & 0.62 & 16.05 & 16.47 \\
\hline ADY $5 \mathrm{~g} / \mathrm{l}$ & 0.35 & 0.32 & 0.88 & 0.86 & 23.52 & 23.04 \\
\hline ADY $10 \mathrm{~g} / \mathrm{l}$ & 0.35 & 0.38 & 0.96 & 1.11 & 25.69 & 29.56 \\
\hline ADY 15 g/l & 0.39 & 0.36 & 0.95 & 0.93 & 25.23 & 24.80 \\
\hline SS 10 ppm & 0.48 & 0.43 & 1.11 & 1.04 & 29.61 & 27.78 \\
\hline SS 20 ppm & 0.52 & 0.44 & 1.25 & 1.10 & 33.38 & 29.35 \\
\hline SS 30 ppm & 0.50 & 0.46 & 1.10 & 1.08 & 29.20 & 28.75 \\
\hline $\mathrm{MgCO}_{3} 10 \mathrm{ppm}$ & 0.40 & 0.36 & 0.87 & 0.80 & 23.08 & 21.31 \\
\hline $\mathrm{MgCO}_{3} 20$ ppm & 0.43 & 0.39 & 0.91 & 0.86 & 24.21 & 22.85 \\
\hline $\mathrm{MgCO}_{3} 30 \mathrm{ppm}$ & 0.46 & 0.40 & 0.92 & 0.86 & 24.61 & 23.00 \\
\hline L.S.D. at 5\% & 0.13 & 0.17 & 0.23 & 0.31 & 3.97 & 5.51 \\
\hline
\end{tabular}

Macronutrients ( $N, P$ and $K$ ) and total carbohydrate percentage

Data presented in Table (4) reported that, the concentrations of macronutrients content (\%) for ( $N, P$ and $\mathrm{K})$ as well as total carbohydrate content (\%) were progressively affected by using different concentrations of antitranspirants, where the highest increment in $\mathrm{N}(\%)$ was found by using S.S at rates of 10 and $20 \mathrm{ppm}$ for the second and first and cuts, respectively during two years. While the highest $P(\%)$ was obtained as a result of using ADY at 10 and $15 \mathrm{~g} / \mathrm{l}$ for the second and first seasons, respectively during two cuts. Also the application of S.S at $20 \mathrm{ppm}$ produced the maximum $\mathrm{K}$ content (\%) except the first cut in the first season and the second cut in the second season which reached its maxima by using S.S at 30 and $10 \mathrm{ppm}$, respectively. 
Table (4) : Effect of foliar application of antitranspirants on some macronutrients $(\mathrm{N}, \mathrm{P}$ and $\mathrm{K}$ ) and total carbohydrate content (\%) of geranium plants in two cuts during both seasons.

\begin{tabular}{|c|c|c|c|c|c|c|c|c|}
\hline \multirow[t]{3}{*}{ Treatments } & \multicolumn{2}{|c|}{ N\% } & \multicolumn{2}{|c|}{$\mathrm{P} \%$} & \multicolumn{2}{|c|}{ K \% } & \multicolumn{2}{|c|}{$\begin{array}{c}\text { Total } \\
\text { carbohydrate \% }\end{array}$} \\
\hline & \multicolumn{8}{|c|}{ First season } \\
\hline & $1^{\text {st }}$ cut & $2^{\text {nd }}$ cut & $1^{\text {st }}$ cut & $2^{\text {nd }}$ cut & $1^{\text {st }}$ cut & $2^{\text {nd }}$ cut & $1^{\text {st }}$ cut & $2^{\text {nd }}$ cut \\
\hline Control & 1.87 & 2.11 & 0.31 & 0.27 & 1.40 & 1.68 & 13.47 & 12.85 \\
\hline ADY $5 \mathrm{~g} / \mathrm{l}$ & 2.45 & 2.73 & 0.47 & 0.39 & 1.49 & 1.70 & 16.53 & 15.39 \\
\hline ADY $10 \mathrm{~g} / \mathrm{l}$ & 2.61 & 2.95 & 0.52 & 0.48 & 1.85 & 1.96 & 17.89 & 17.80 \\
\hline ADY $15 \mathrm{~g} / \mathrm{l}$ & 3.14 & 2.84 & 0.63 & 0.56 & 1.93 & 2.07 & 18.29 & 17.14 \\
\hline SS 10 ppm & 3.35 & 3.81 & 0.48 & 0.42 & 2.11 & 2.53 & 17.44 & 16.42 \\
\hline SS 20 ppm & 4.03 & 3.42 & 0.39 & 0.47 & 2.47 & 2.87 & 16.59 & 16.98 \\
\hline SS 30 ppm & 4.00 & 3.47 & 0.31 & 0.47 & 2.75 & 2.80 & 15.91 & 14.53 \\
\hline $\mathrm{MgCO}_{3} 10 \mathrm{ppm}$ & 2.69 & 2.14 & 0.35 & 0.41 & 1.80 & 2.14 & 14.25 & 14.32 \\
\hline $\mathrm{MgCO}_{3} 20 \mathrm{ppm}$ & 2.85 & 2.80 & 0.42 & 0.38 & 1.91 & 2.16 & 15.67 & 13.59 \\
\hline $\mathrm{MgCO}_{3} 30 \mathrm{ppm}$ & 2.49 & 2.51 & 0.33 & 0.35 & 1.84 & 1.79 & 13.89 & 13.11 \\
\hline L.S.D. at $5 \%$ & 1.37 & 1.04 & NS & NS & 0.46 & 0.34 & 2.68 & 3.09 \\
\hline \multicolumn{9}{|c|}{ Second season } \\
\hline Control & 2.27 & 2.68 & 0.25 & 0.29 & 1.34 & 1.58 & 11.30 & 11.66 \\
\hline ADY $5 \mathrm{~g} / \mathrm{l}$ & 2.80 & 3.15 & 0.36 & 0.47 & 1.65 & 1.93 & 14.82 & 15.78 \\
\hline ADY $10 \mathrm{~g} / \mathrm{l}$ & 3.21 & 3.72 & 0.44 & 0.52 & 1.74 & 2.10 & 15.63 & 17.94 \\
\hline ADY $15 \mathrm{~g} / \mathrm{l}$ & 3.64 & 4.18 & 0.41 & 0.50 & 1.82 & 2.17 & 16.75 & 17.16 \\
\hline SS $10 \mathrm{ppm}$ & 4.17 & 4.91 & 0.40 & 0.43 & 1.85 & 2.45 & 13.95 & 14.08 \\
\hline SS 20 ppm & 4.83 & 4.75 & 0.37 & 0.48 & 1.93 & 2.31 & 15.40 & 13.99 \\
\hline SS 30 ppm & 4.58 & 4.79 & 0.30 & 0.42 & 1.80 & 1.96 & 14.28 & 13.21 \\
\hline $\mathrm{MgCO}_{3} 10 \mathrm{ppm}$ & 4.61 & 3.92 & 0.29 & 0.35 & 1.65 & 2.12 & 12.62 & 13.75 \\
\hline $\mathrm{MgCO}_{3} 20 \mathrm{ppm}$ & 4.18 & 4.16 & 0.36 & 0.30 & 1.40 & 2.20 & 13.55 & 12.49 \\
\hline $\mathrm{MgCO}_{3} 30 \mathrm{ppm}$ & 4.21 & 3.89 & 0.32 & 0.31 & 1.37 & 1.74 & 12.19 & 12.51 \\
\hline L.S.D. at $5 \%$ & 2.01 & 1.29 & NS & NS & 0.35 & 0.41 & 3.19 & 3.87 \\
\hline
\end{tabular}


Finally, the treatments of ADY at 10 and $15 \mathrm{~g} / \mathrm{l}$ produced the maximum total carbohydrate (\%) for the second and first cuts, respectively during two years. The proper balance of moisture in plant as a result of using antitranspirants create a favorable conditions for metabolic and enzymes activity, protein synthesis and photosynthesis and metabolites translocation (Javan et al., 2013) which accelerate the rates of nutrients uptake. In this respect, Abd El-Aal et al. (2008) mentioned that, foliar addition of antitranspirants gained more enhancement in growth and fruit yield as well as chemical properties of eggplant compared with the control. Also it play important role for reduce heat stress injury and this reflect on mineral and nutrient absorption. These results are in agreement with Kamal (2013) on sweet pepper plants and El-Said (2015) on eggplants.

\section{Photosynthetic pigments}

It is obvious from Table (5) that, photosynthetic pigments such as chlorophyll a, b as well as carotenoids ( $\mathrm{mg} / \mathrm{g}$ of fresh leaves) were higher by using any concentrate of antitranspirant agents. The application of S.S at $30 \mathrm{ppm}$ produced the highest contents of chlorophyll $a$ in two cuts during two seasons except the first cut through the first season which reached its maxima by using $S . S$ at $20 \mathrm{ppm}$. Also, using S.S at $20 \mathrm{ppm}$ produced the highest content of chlorophyll $b$ in two cuts during both seasons except the first cut in the first season and the second cut in the second season which reached its maxima by using S.S at $10 \mathrm{ppm}$ and $30 \mathrm{ppm}$, respectively. Finally, the best enhancement in carotenoids were done by adding $\mathrm{MgCO}_{3}$ at $10 \mathrm{ppm}$ except the second cut in the first season and the first cut during second season which reached its maximum values by using $\mathrm{MgCO}_{3}$ at $20 \mathrm{ppm}$ and S.S at $30 \mathrm{ppm}$, respectively. Antitranspirants may be relieve the effect of water stress on photosynthetic pigments by improving endogenous levels of cytokinins, which encourage the synthesis of chlorophyll (Samir, 1988). Also our results appeared more enhancement in both nitrogen and potassium contents in geranium plants as shown in (Table 4), which may be have a vital part in rising cell number and size per unit area, number of chloroplasts per cell and increased synthesis of chlorophyll (Possingham, 1980). Similar results were confirmed by Ezzat et al. (2009) they stated that, foliar application of antitraspirant significantly increased photosynthetic pigments, i.e., chlorophyll $a, b$ and carotenoids in the leaves of potato plants.

\section{Essential oil composition}

Data in Table (6) reported that, there were 8 components were identified for the essential oil of Pelargonium graveolens. The highest concentrations of geranyl butyrate, geranyl tiglate and cis-rose oxide were found by using S.S at 10,20 and 30 ppm, respectively.

While the application of $\mathrm{MgCO}_{3}$ at 20 ppm produced the highest concentrations of citronellol, citronellyl formate and isomenthone. Also, the best improvement in geraniol and linalool were found by the application of ADY at 10 and $15 \mathrm{~g} / \mathrm{l}$ in the second cut during the first season. 
Influence of some compounds as antitranspirant agents on growth

Table (5) : Effect of foliar application of antitranspirants on photosynthetic pigments of geranium plants in two cuts during both seasons.

\begin{tabular}{|c|c|c|c|c|c|c|}
\hline \multirow{3}{*}{ Treatments } & \multicolumn{2}{|c|}{ Chlorophyll A } & \multicolumn{2}{|c|}{ Chlorophyll B } & \multicolumn{2}{|c|}{ Carotenoids } \\
\hline & \multicolumn{6}{|c|}{ First season } \\
\hline & $1^{\text {st }}$ cut & $2^{\text {nd }}$ cut & $1^{\text {st }}$ cut & $2^{\text {nd }}$ cut & $1^{\text {st }}$ cut & $2^{\text {nd }}$ cut \\
\hline Control & 2.21 & 1.97 & 1.06 & 0.85 & 1.69 & 1.18 \\
\hline ADY $5 \mathrm{~g} / \mathrm{l}$ & 2.37 & 2.18 & 1.10 & 0.97 & 1.73 & 1.20 \\
\hline ADY $10 \mathrm{~g} / \mathrm{l}$ & 2.68 & 2.45 & 1.18 & 1.15 & 1.84 & 1.46 \\
\hline ADY $15 \mathrm{~g} / \mathrm{l}$ & 3.17 & 2.56 & 1.62 & 1.29 & 1.79 & 1.65 \\
\hline SS 10 ppm & 3.95 & 2.81 & 1.97 & 1.60 & 1.95 & 2.03 \\
\hline SS 20 ppm & 4.36 & 3.14 & 1.80 & 1.86 & 2.19 & 2.15 \\
\hline sS 30 ppm & 3.89 & 3.25 & 1.53 & 1.78 & 1.70 & 1.98 \\
\hline $\mathrm{MgCO}_{3} 10 \mathrm{ppm}$ & 3.18 & 2.65 & 1.43 & 1.20 & 2.32 & 1.81 \\
\hline $\mathrm{MgCO}_{3} 20 \mathrm{ppm}$ & 3.51 & 2.50 & 1.67 & 1.26 & 2.15 & 2.25 \\
\hline $\mathrm{MgCO}_{3} 30 \mathrm{ppm}$ & 3.40 & 2.37 & 1.29 & 1.14 & 1.86 & 1.68 \\
\hline L.S.D. at 5\% & 1.05 & 0.89 & 0.48 & 0.61 & NS & 0.42 \\
\hline \multicolumn{7}{|c|}{ Second season } \\
\hline Control & 2.71 & 2.58 & 1.16 & 1.23 & 1.46 & 1.58 \\
\hline ADY $5 \mathrm{~g} / \mathrm{l}$ & 3.12 & 2.94 & 1.35 & 1.75 & 1.58 & 1.79 \\
\hline ADY $10 \mathrm{~g} / \mathrm{l}$ & 3.52 & 3.05 & 1.48 & 1.83 & 1.66 & 1.90 \\
\hline ADY $15 \mathrm{~g} / \mathrm{l}$ & 3.24 & 3.18 & 1.49 & 1.57 & 1.71 & 2.11 \\
\hline SS 10 ppm & 3.77 & 3.86 & 1.53 & 1.67 & 1.59 & 2.14 \\
\hline SS 20 ppm & 3.91 & 4.15 & 2.12 & 1.96 & 2.16 & 2.23 \\
\hline SS 30 ppm & 4.23 & 4.20 & 2.08 & 2.31 & 2.48 & 2.05 \\
\hline $\mathrm{MgCO}_{3} 10 \mathrm{ppm}$ & 3.18 & 2.89 & 1.68 & 1.37 & 1.89 & 2.30 \\
\hline $\mathrm{MgCO}_{3} 20 \mathrm{ppm}$ & 3.50 & 3.40 & 1.75 & 1.41 & 1.65 & 2.18 \\
\hline $\mathrm{MgCO}_{3} 30 \mathrm{ppm}$ & 3.67 & 3.35 & 1.45 & 1.52 & 1.82 & 2.13 \\
\hline L.S.D. at 5\% & 1.23 & 1.12 & 0.76 & 1.01 & 0.74 & 0.50 \\
\hline
\end{tabular}


Table (6): Effect of foliar application of antitranspirants on essential oil composition of geranium plants during second cut in the first season.

\begin{tabular}{|c|c|c|c|c|c|c|c|c|}
$\begin{array}{c}\text { Oil constituents } \\
\text { Treatments }\end{array}$ & Citronellol & Geraniol & Linalool & $\begin{array}{c}\text { Citronellyl } \\
\text { formate }\end{array}$ & Isomenthone & $\begin{array}{c}\text { Geranyl } \\
\text { Butyrate }\end{array}$ & $\begin{array}{c}\text { Geranyl } \\
\text { Tiglate }\end{array}$ & $\begin{array}{c}\text { Cis-rose } \\
\text { oxide }\end{array}$ \\
\hline Control & 0.64 & 5.14 & 4.54 & 8.35 & 7.15 & 11.90 & 24.08 & 34.14 \\
\hline ADY $5 \mathrm{~g} / \mathrm{l}$ & 0.58 & 5.35 & 4.73 & 7.42 & 8.03 & 11.19 & 20.62 & 36.90 \\
\hline $\mathrm{ADY} 10 \mathrm{~g} / \mathrm{l}$ & 0.91 & 5.91 & 4.34 & 7.84 & 7.29 & 12.52 & 21.85 & 36.66 \\
\hline $\mathrm{ADY} 15 \mathrm{~g} / \mathrm{l}$ & 1.11 & 5.60 & 4.89 & 7.19 & 8.42 & 12.47 & 19.30 & 37.89 \\
\hline $\mathrm{SS} 10 \mathrm{ppm}$ & 1.25 & 4.89 & 4.03 & 7.30 & 7.89 & 15.69 & 23.55 & 33.73 \\
\hline $\mathrm{SS} 20 \mathrm{ppm}$ & 0.63 & 3.75 & 3.20 & 6.52 & 8.11 & 14.78 & 25.19 & 36.60 \\
\hline $\mathrm{SS} 30 \mathrm{ppm}^{2}$ & 0.26 & 2.99 & 2.66 & 7.79 & 8.25 & 12.50 & 24.77 & 39.19 \\
\hline $\mathrm{MgCO}_{3} 10 \mathrm{ppm}$ & 1.08 & 4.05 & 3.93 & 8.31 & 8.65 & 13.83 & 22.46 & 32.88 \\
\hline $\mathrm{MgCO}_{3} 20 \mathrm{ppm}$ & 1.32 & 4.40 & 2.80 & 8.60 & 9.13 & 10.92 & 23.28 & 34.71 \\
\hline $\mathrm{MgCO}_{3} 30 \mathrm{ppm}$ & 0.91 & 5.12 & 3.45 & 7.55 & 8.39 & 11.67 & 22.15 & 36.40 \\
\hline
\end{tabular}

\section{REFERENCES}

Abd El-Aal, F. S., M. M. Abd El-Mouty and

A. H. Ali (2008). Combined effect of irrigation intervals and foliar application of some antitranspirants on eggplant growth, fruits yield and its physical and chemical properties. Res. J. Agric. and Biol. Sci., 4(5): 416423.

Barbara, F.R. and L.J. Brain (1994). Minitab Hand Book. Duxbury Press. An Imprint of Wad Sworth Publish. Comp., Belonont, California.

Bittelli, M., M. Flury, G.S. Campbell and E.J. Nichols (2001). Reduction of transpiration through foliar application of Chitosan. Agricultural and Forest Meteorology. 107: 167-175.

Bose, T. K., S. K. Mitra and D. Sanyal (2001). Fruits-Tropical and SubTropical. Naya Udyog. pp.100-105.

British, P. (1963). Determination of Volatile Oil in Drugs. The
Pharmaceutical Press 17 Bloomsburg, square. W.C.I. London.

Cantore, V., B. Pace and R. Albrizio (2009). Kaolin-based particle film technology affects tomato physiology, yield and quality. Environmental and Experimental Botany 66, 279-288.

Chapman, H.D. and P.F. Pratt (1982). Methods of Plant Analysis. I. Methods of Anaylsis for Soil, Plant and Water. Chapman Publishers, Riverside, California, USA.

Cottenie, A., M. Verloo, L. Kiekens, G. Velghe and R. Camerlynck (1982). Chemical Analysis of Plants and Soils. Lab. Analytical and Agrochem, State Univ., Ghent-Belgium.

Del Amor, F.M., P. Cuadra-Crespo, D.J. Walker, J.M. Camara and C.R. Madrid (2010). Effect of foliar application of antitranspirant on photosynthesis and water relations of pepper plants under different levels of $\mathrm{CO} 2$ and water 
stress. J. Plant Physiol. 167:12321238.

Dubois, M., K.A Gilles, J.K. Hamilton, P.A. Robers and F. Smith (1956). Calorimetric method for determination of sugars and related substance.Anal. Chem. 28; 350-356.

El- Said, E.M. (2015). Effect of irrigation intervals and some antitranspirants on growth, yield and fruit quality of eggplant. J. Plant Production, Mansoura Univ.,6 (12): 2079- 2091.

Ezzat, A. S., U. M. Saif El-deen and A. M. Abd El-Hameed (2009). Effect of irrigation water quantity, antitranspirant and humic acid on growth, yield, nutrients content and water use efficiency of potato (Solanum tuberosum L.). J. Agric. Sci., Mansoura Univ., 34(12):11585 11603.

Fukutoka, Y. and K. Terai (1996). Effect of film forming antitranspirant and the water status of soybeans. Bulletin of the faculty of Agriculture. Saga university 81, 1-5.

Ibrahim, E.A. and E.M. Selim (2010). Effect of irrigation intervals and antitranspirants (Kaolin) on summer squash (Cucurbita pepo L.) growth, yield quality and economics. Journal of Soil Science and Agriculture Engineering, Mansoura University 1, 883-894.

Javan, M., M. Tajbakhsh and A. Mandoulakani (2013). Effect of antitranspirant application on yield and yield components in soybean (Glycine max L.) under limited irrigation. J. Appl. Biol. Sci. 7:70-74.

Jifon, J.L. and J.P. Syvertsen (2003). Kaolin particle film application can increase photosynthesis and water use efficiency of 'Ruby Red' grapefruit leaves. J. Amer. Soc. Hort. Sci. 128:107-112.

Kamal, A. M. (2013). Influence of irrigation levels, antitranspirants and potassium silicate on growth, fruit yield and quality of sweet pepper plants (Capsicum annuum L.) grown under drip irrigation. J. Plant Production, Mansoura Univ.,4 (11): 1581 - 1597.

Kim, H. T. (1996). "Soil Sampling, Preparation and Analysis". Marcel Dekkerlnc., New York, p. 391.

Leithy, S.M., B. Abou Leila, E.F. Abdallah and M.S. Gaballah (2015). Response of canola plants to antitranspirant levels and limited irrigation. AmericanEurasian Journal of Sustainable Agriculture. 9(4): 83-87.

Miller, D.M. (2002). The taxonomy of pelargonium species and cultivars, their origins and growth in the wild. geraniums and pelargoniums: The genera geranium and pelargonium. In. Lis-Balchin, M. (Ed.), Medicinal and Aromatic Plants-Industrial Profiles. Taylor and Francis Inc., London, pp. 49-79.

Nasraui, B. (1993). Role of antitranspirant films in protecting plants against fungal disease. Annals de I'Institute National de la Recherche Agronomique de Tunisie 66, 125-135.

Page, A. L., R. H. Miller and D. R. Keeney (1982). "Methods of Soil Analysis". II. Chemical and Microbiogical Properties. 2nd Ed. Madison, Wisconsin, U. S. A.

Peterson, A., M. Goto, S.B. Machmuah, B.C. Roy, M. Sasaki and T. Hirose (2005). Extraction of essential oil from geranium (Pelargonium graveolens) with supercritical carbon dioxide. Journal of Chemical Technology and Biotechnology, 81: 167-172.

Pinto, T.M. and J.M.G. Torres-Pereira (2006). Bark stripping in cork oak (Quercus suber L.): effect of an antitranspirant application on gas exchange and water relations of the stripped surface. Trees 20:247-252.

Possingham, J.V. (1980). Plastid replication and development in the life 
cycle of higher plants. Annual Review of Plant Physiology 31: 113-129.

Prakash, M. and K. Ramachandran (2000). Effects of chemical ameliorants in brinjal (Solanum melongena L.) under Moisture Stress Conditions." J. Agro. Crop Sci., 185: 237-239.

Rao, B.R.R. (2002). Cultivation and distillation of geranium oil from Pelargonium sp. in India: Indian perspective. Paper: National Seminar on the Research and Development in Aromatic Plants: Trends in Biology, Uses, Production and Marketing of Essential Oils. Central Institute of Medicinal and Aromatic Plants, Lucknow, India.

Samir, A.Z.M. (1988). Water use efficiency, growth and yield of corn as influenced by antitranspirant materials. MSc thesis, Ain Shams University, Cairo, Egypt.

Shawl, A.S., T. Kumar, N. Chishiti and S. Shabir (2006). Cultivation of rose scented geranium (Pelargonium sp.) as a cash crop in Kashmir Valley.
Asian Journal of Plant Sciences, 5(4): 673-675.

Singh, M., S. Singh and M. Yaseen (2008). Standardization of planting time for optimum growth and oil production of geranium (Pelargonium graveolens L. Her.) under north Indian plains. Journal of Spices and Aromatic Crops, 17(3): 247-250.

Tezara, W., V. J. Mitchell, S. D. Driscoll and D. W. Lawlor (1996). Water stress inhibits plant photosynthesis by decreasing coupling factor and ATP. J. Macmillan, Vol. 401: 913-917.

Verma, R.K., Laiq-ur-Rahman; R.S. Verma, A. Kalra, A.K. Kukreja, A.S. Bisht, A. Chauhan, and S.P.S. Khanuja (2011). Assessing N-use efficiency, planting time and economics of fertilizer $N$ in rose-scented geranium (Pelargonium graveolens L' Herit) in Western Himalayan Region of India. African Journal of Agricultural Research, 6(3): 553-559.

Witham, F. H., D. F. Blaydes and R. M. Devlin (1971). Experiments in Plant Physiology. Van Nostr and Reinhold Co., New York. pp. 55-58. 
تأثير بعض المركبات كمواد مضادة للنتح علي نمو ومحصول نبات العتر

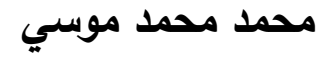 \\ قسم البساتين - كلية الزراعة - جامعة المنوفية - شبين الكوم- مصر مبدي
}

الملخص العربي

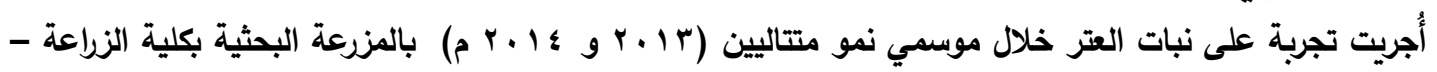

جامعة المنوفية - شبين الكوم - مصر ـ وإن هذة الدراسة صمدت لتقدير كفاءة المواد المضادة للنتح مثل كربونات

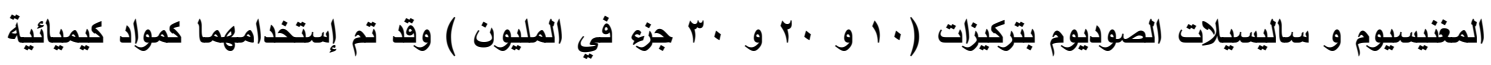

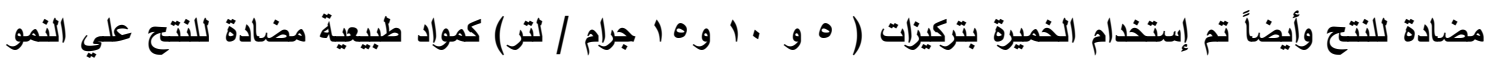

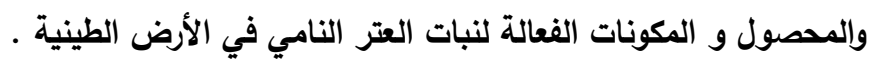

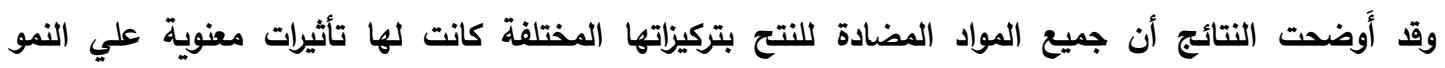

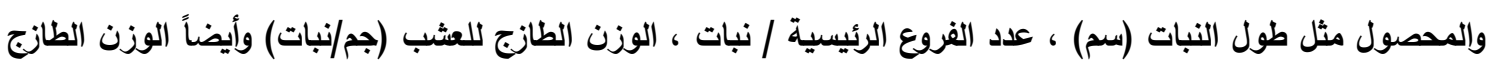

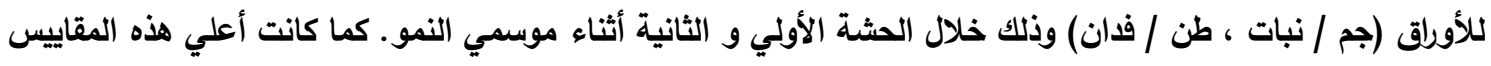

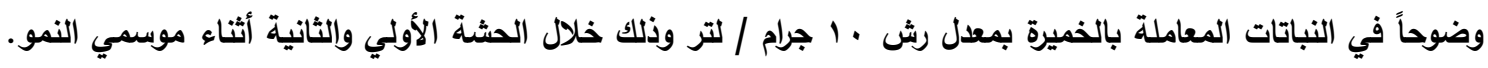

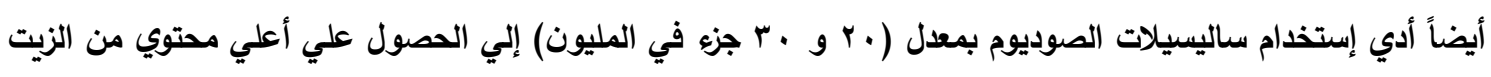

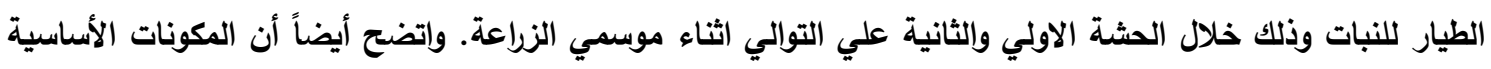

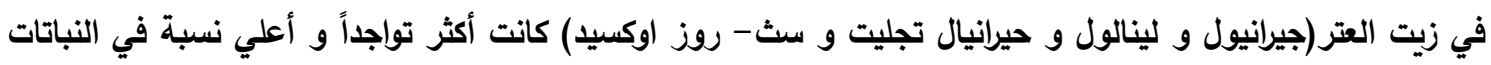

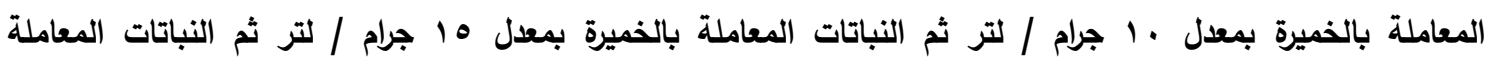

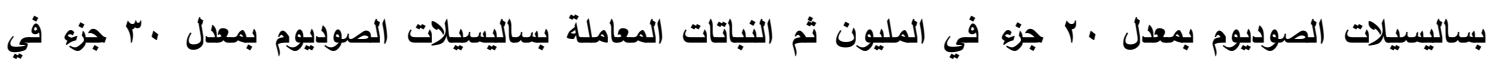

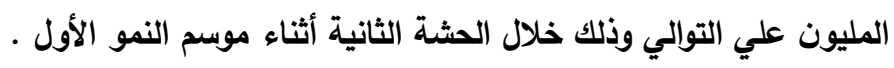

\footnotetext{
أسماء السمادة المحكمين

أ.د/ على عبدالحميد معوض المبين كلية الزراعة- الزقازيق

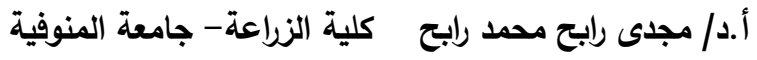


